\title{
The Challenges Faced Across South-south Cooperation
}

\author{
Shailly Nigam \\ Department of Management, Prince Sattam Bin Abdulaziz University, Al Kharj, Saudi Arabia
}

Email address:

drshaillytiwari@gmail.com

\section{To cite this article:}

Shailly Nigam. The Challenges Faced Across South-south Cooperation. Journal of World Economic Research. Special Issue: The Globalization and Economic Structure Changes. Vol. 4, No. 5-1, 2015, pp. 27-32. doi: 10.11648/j.jwer.s.2015040501.14

\begin{abstract}
South-South cooperation (SSC) elucidates the cooperation made by developing countries to find mutual solutions for common constraints faced by development of the state. Connected by likenesses in their development settings and challenges, the nations of the South have been ever more vigorous in cooperating with each other in terms knowledge sharing, technology exchange, and common programme formation and collective action initiation. Consequently, SSC aims to stimulate self-reliance among the countries of global south and to reinforce their economic relationships. This paper analyses the performance of various countries as a participant in the south-south cooperation and makes an investigation into the challenges faced by them in the due course. Budgets of southern contributors have been investigated and analysis has been made to evaluate the contributions made by various countries to other developing economies. It has also been taken into account that how much has been the impact of the donor participant on the receiving country's economy. The study concludes the findings in form of the challenges faced by south-south cooperation, the most predominant of which emerges due to the lack of a universally accepted definition of the term south-south cooperation. The paper also makes suggestions to the contributors to overcome those challenges.
\end{abstract}

Keywords: Globalisation, Development Economics, Economics of Growth, South-South Cooperation

\section{Introduction}

The global economic backdrop is witnessing rapid change in terms of international cooperation in order to promote mutual economic growth among the nations. The emerging and other developing economies have come to the fore as the most significant actors in designing and implementing the new development policies and programmes across the developing world. This cooperation in the fields of knowledge exchange and technology transfer among southern economies of the world is growing in both incidence and intricacy. It is increasingly comprising of extending economic support as well as cooperation in the domains of wellbeing, training, communication, research, and development. The participating countries suggest concrete solutions, provide adequate awareness, offer guidance and contribute in joint activities.

This broad notion comprising of a highly comprehensive variety of partnership amid developing nations is usually observed to consist of three scopes, namely: political, economic and technical, and is collectively known as southsouth cooperation (SSC).

South-south cooperation has a purpose of endowing the people of developing nations with an improved the quality of life and recognise the speciality and relative lead of every nation in its capability to impact the development programme. SSC has broadly the distinctive features of ensuring capacity development; providing a broader choice of support, leading to horizontal partnerships; guaranteeing cost effectiveness; being demand-driven in nature; providing highly-adapted and relevant solutions and last, but not the least, diversifying knowledge and expertise beyond industrialized models.

At the same as above, the political element of the southsouth cooperation cannot be ignored, especially because one of the key features of SSC is transformation and at times, restructuring of the international order and the global economic structure. Apart from this component, the SSC has to successfully ensure coverage, impact, and sustainability of the development innovation. It includes increasing effective schemes and improving international, national and local strategies and organisations. It is in this context that SSC faces certain challenges which make the effectiveness of the actions of participants substantially inadequate.

This paper is organized as follows. Section II presents an insight into the methodology used to gauge the effectiveness 
of the south-south cooperation in recent years. It also reviews issues relating to methodology, coverage, and data collection techniques employed in this study. Section III makes an investigation into the challenges faced by the participants in south-south cooperation across the globe and analyses various short comings the cooperation faces. Section IV presents the results of the study and Section $\mathrm{V}$ concludes the research on the basis of the findings and discussions made.

\section{Methodology}

\subsection{Coverage}

In the global development cooperation order, donors are usually demarcated as those nations which are members of

- Organisation for Economic Co-operation and Development (OECD) and help their mutual participants in promoting policies to improve the economic and social security of populaces across the world, and

- main multilateral bodies and international financial institutions , for example, the World Bank and the International Monetary Fund (IMF), and regional development banks, such as the Asian Development Bank (AsDB), African Development Bank (AfDB), and Inter-American Development Bank (IADB).

The present study refers the developing countries or economies providing aid as southern bilateral contributors. This definition omits developed countries. Similarly southern multilateral institutions refer to institutions owned by southern bilateral contributors.

\subsection{Scope of Official Development Assistance}

In scrutinising the developments in south-south cooperation, it is imperative to be precise in various definition. Peripheral financial resources existing for developing economies can be categorised into two main groups:

(a) concessional finance or development assistance and

(b) non-concessional or market-related finance.

There is no universally accepted definition of the term development assistance or the concessional finance. Yet, if we take a 1969 OECD definition into account, official development assistance (ODA) comprises of grants or loans, which satisfy the following conditions:

- The donor is a government or its agency;

- The recipient is a developing country government or multilateral development institution;

- The funding being provided is for the purpose of promoting economic development and welfare.

To lessen the room for individual version and to boost analogous data reporting, the OECD excludes the following as ODA:

- military assistance

- administrative assistance in peacekeeping

- policy assistance to check civil disobedience

- funding concert tours or travelling of athletes'
- assistance to refugees with over one year stay in the donor country

- military uses of nuclear energy

- aid or credit for representational or commercial purposes

- export credits provided by a donor country

- loans with around one year's maturity

- grant less than 25 per cent

- grants to the private sector to relax its lending to developing countries

- The categories of flows considered as ODA are:

- programme and project assistance

- humanitarian assistance

- debt relief

- costs of education provided by the donor country

- administrative costs of ODA programmes

- subsidies to NGOs

- programmes to raise development awareness in donor countries

\subsection{Data Collection}

Data collection remains to be a huge constraint in the analysis of official development assistance in south-south cooperation. This can be attributed to the lack of accessible and exhaustive data and information.

The data for this study was collected mainly from the publications of organisations accountable for executing programmes pertaining to south-south concessional finance. Despite earnest efforts, in-depth analysis was restricted mainly due to data generally not being comparable and certain cracks in information. The dearth of data on philanthropic support extended by many donors further complicated the research.

\section{Discussion}

Development assistance has long been acknowledged as critical to assist developing countries to augment their rate of growth and economic development. As donors are investing increasingly in multilateral cooperation, the complexities are increasing.

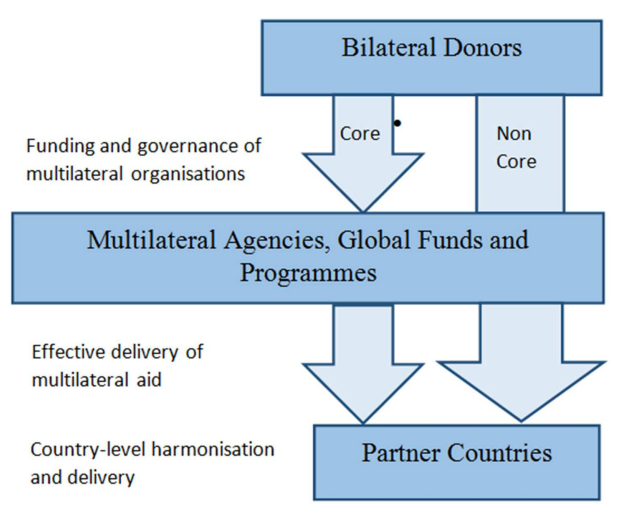

Source: Developed by Author on the basis of OECD data.

Figure 1. Conceptual framework for classifying key initiatives for multilateral effectiveness to date. 
To ease the understanding, OECD categorises the multilateral aid into core or non-core assistance. While core aid refers to un-earmarked contributions made to multilateral organisations, non-core aid comprises of the contributions made to multilateral organisations for specific purposes, sectors, regions or countries. Figure 1 shows conceptual framework for classifying key initiatives for multilateral effectiveness.

Combining the core and the non-core development assistance, the members of Development Assistance Committee (DAC) used to contribute nearly all development cooperation flows worldwide till the end of 1990s. Though DAC members continue to extend the majority of the development assistance, there has been an increased upsurge in the disbursements made by non-DAC donors. Collectively, the 27 nations apart from the DAC members gave USD 23.5 billion of gross development cooperation in 2013, which was more than an overall global aggregate of 13 per cent. Table 1 exhibits the details about the same.

That said, the figures given below in Table 1 most likely underestimate total south-south development cooperation as neither data is exhaustive nor does it exhibit the flows of numerous less important bilateral and multilateral assistances. Almost all south-south development assistance has been in the form of project loans and grants as also technical collaboration schemes.

Table 1. Concessional finance for development of key providers of development co-operation that do not report to the OECD-DAC (Gross disbursements in USD million).

\begin{tabular}{lllll}
\hline Country & $\mathbf{2 0 1 0}$ & $\mathbf{2 0 1 1}$ & $\mathbf{2 0 1 2}$ & $\mathbf{2 0 1 3}$ \\
\hline Brazil & 500 & n.a. & n.a. & n.a. \\
Chile & 16 & 24 & 38 & 44 \\
China & 2,561 & 2,776 & 3,114 & 3,009 \\
Colombia & 15 & 22 & 86 & 95 \\
India & 709 & 788 & 1,076 & 1,257 \\
Indonesia & 10 & 17 & 27 & 12 \\
Mexico & n.a. & 99 & 203 & n.a. \\
Qatar & 334 & 733 & 543 & 1,344 \\
South Africa & 151 & 227 & 188 & 183 \\
\hline
\end{tabular}

Source: Feb 2015 OECD Data.

Several smaller southern cooperation donors such as Argentina, Turkey, Chile, Egypt, Korea, Thailand and Singapore have provided technology exchange platforms, for around 30 years. China has always been focussed to offer technical assistance, one such example being Chinese assistance to the Tazara Railway. India is also estimated to have disbursed over US\$4 billion of technical support to 156 developing countries. Despite this, technical assistance remains a comparatively minor constituent of support lent by southern multilateral institutions.

Due to lack of availability of data, the extent of philanthropic and exigency support under south-south is not eminent. But it is a well-known fact that is known is that southern contributors extended support during calamitous occasions, such as the Indian and South Asian countries' assistance during the Indian Ocean tsunami and torrents in
Bangladesh. Latin American donors too provided substantial aid during Hurricane and Guyana floods. South Africa has been a front runner in providing philanthropic support to the African countries during cyclones, droughts and floods. Similarly, Arab donors have been extending exigency support to Lebanon, West Bank and Gaza in recent times.

The growth of multilateral ODA has reduced over recent years, reflecting the slackening global growth in ODA which dropped from $9 \%$ in 2008 to $5 \%$ in 2010 and further to $1 \%$ in 2011. This slackening movement is likely to linger on due to most of the governments being asked to examine and possibly restrict multilateral aid.

As a consequence, at the Fourth High-Level Forum in Busan in 2011, an agreement was made to develop the consistency of policies on multilateral institutions, global funds and programmes and also a substantial reduction of the proliferation of such channels. To do so, the countries and organisations also vouchsafed to make effective utilisation of multilateral networks, centring on those which have better performance. This obligation trails a long standing efforts enabled by the UN, the OECD, and southern contributors to recognise upright practices in finance, assessment and delivery of multilateral cooperation.

Subsequently, non-core multilateral assistance grew from 2009 to 2010 by 8 per cent. In 2014, philanthropic assistance comprised of $29 \%$ of non-core multilateral aid, $45 \%$ per cent of multilateral assistance remains unassigned on the basis of country, but was set aside for a definite region, theme, and segment. Of the $55 \%$ that was allocated to go to specific nations, majority is laid out to weak and conflict-torn and/ or low-income economies. The multilateral funding has thus upheld its significance as a network for contributors to be accessible by the poorest and weakest economies.

Table 2. Advantages and disadvantages of non-core contributions.

\begin{tabular}{|c|c|}
\hline $\begin{array}{l}\text { From the } \\
\text { perspective of: }\end{array}$ & Advantages \\
\hline $\begin{array}{l}\text { Developing } \\
\text { countries }\end{array}$ & $\begin{array}{l}\text { - can result in a higher representative control; } \\
\text { leads to better coordination when compared } \\
\text { with bilateral initiatives. }\end{array}$ \\
\hline $\begin{array}{l}\text { Multilateral } \\
\text { organisations }\end{array}$ & $\begin{array}{l}\text { superior to several comparable bilateral } \\
\text { initiatives in case of multiple donors; } \\
\text { preferable to the formation of new organisations } \\
\text { or policies for specific, critical, time-bound } \\
\text { purposes }\end{array}$ \\
\hline Bilateral donors & $\begin{array}{l}\text { can be focused on specific sectors, regions or } \\
\text { countries (including fragile states) where the } \\
\text { bilateral donor may lack expertise or has no } \\
\text { presence; } \\
\text { can make contributions more visible as the } \\
\text { funding "keeps its identity" by not being } \\
\text { pooled; } \\
\text { - can bypass cumbersome board decisions; } \\
\text { - can serve as "pilot" for stand-alone funds. }\end{array}$ \\
\hline
\end{tabular}

Source: OECD Data

There have been several humanitarian assistance programmes on regional as well as national basis, such as the Brazilian bolsa familia programme which helped in improving child nutrition and education in Brazil, and has 
been effectively implemented in Africa too. Similarly, National Rural Employment Guarantee scheme in India ensures each rural household a providence of 100 days of unskilled work per year on public works programmes. Likewise, China emphasises on infrastructure development in its own territory as well as that of other developing countries, resulting in advances in electricity supply, an escalation in railway networks and decreased prices for telecommunication amenities.

Further, in support of the Paris Declaration, Global Health Partnerships adopted Best Practice Principles for Engagement of Global Health Partnerships at Country Level at their High-Level Forum on Health Millennium Development Goals (MDGs) in Paris in 2005. These were health-specific guidelines based on the Paris Declaration that outlined how Global Health Partnerships should implement the five principles of effective aid at the country level.

The countries agreed to follow "best practice principles" resulting from adapting of the Global Health Partnership. The following are the fundamental bases in the Paris Declaration on Aid Effectiveness:

- Ownership: Global Health Partnerships hold the southern contributor in high opinion and accept its leadership to bolster their capability to exercise it.

- Alignment: Global Health Partnerships base their complete assistance on partner nation's development policies, organisations and techniques.

- Harmonisation: Global Health Partnerships' actions are more consistent, clear and mutually effective. Global Health Partnerships cooperate at the international level with other associates to address issues such as health system consolidation.

- Managing for results: Global Health Partnerships collaborate with countries to embrace and reinforce national results-based management.

- Accountability: Global Health Partnerships extend welltimed, transparent and exhaustive information. The OECD 2012-2015 Survey on Donors' Forward Spending Plans reported that seven DAC members anticipate to reduce their multilateral ODA in material terms in near future.

\section{Results}

Southern contributors are expressing an ever increased reliance on the multilateral system as much as they do today. This has resulted in the total use of the multilateral system (core as well as non-core resources) represents $40 \%$ of gross ODA. The multilateral system is growing in complexity, with many types of organisations delivering assistance in a variety of forms. Contributors and governments use the multilateral system to invest and channel large amounts of money to help countries develop, and they have a responsibility to ensure that the people they are targeting reap the benefits. Yet this is an increasingly difficult task.

The probable beginning of a downslide in financing for multilateral assistance is now on the verge of reversing the trend of sustained growth over the past decade. Heavy budget restraints in most of the OECD nations have resulted in all assistance, comprising of the providences made under the multilateral structure, come under high inspection. This, in turn, has resulted in an escalated predominance of the standards to gauge the execution of such systems. Further, effectiveness of aid also results from a dearth of coherence usually from the guidelines and procedures of bilateral providers.

Rising non-core assistance to multilateral institutions adds to additional disintegration of aid. Since it may be sometimes irrelevant, undesirable or impossible to escalate or transfer disbursements, it is important to develop cognizance of the logic behind non-core assistance to conform up to agreements made under the Busan commitments.

This disintegration of bilateral and multilateral assistance rises when it is ascribed to the non- categorisation of aid. If both bilateral and multilateral contributors are comparatively worse off when the non-core funding is considered, the multi-bilateral trade will not reap any advantages to the receiver. It is significant to remember that this evaluation of fragmentation on the basis of reattribution does not gauge other significant elements, for example funding inspiration.

Further, the past decade has seen much work aimed at bringing multilateral cooperation into line with the principles of aid effectiveness.

\section{Conclusion}

South-south cooperation generally refers to a process where mainly middle income countries (MICs) associate with low income countries (LICs) in a non-traditional way with the aim of economic cooperation. The contributors may provide assistance in form of capacity building, partnership development, lower transaction costs, stronger economic ties and unification of economic, human, institutional, technological and infrastructural resources and networks.

Nevertheless, effectiveness of south-south cooperation is doubted due to the complexities regarding the ownership or management, lack of harmony on implementation of the recommendations of commercial policy, lack of well-defined national policies, uneven shared benefits among developing countries, limited documented information on south-south success stories, resource scarcity, trade barriers and political problems. Notwithstanding the scepticism, it is anticipated that south-south cooperation will make the partner countries learn winning strategies and set their economies on the path of development.

Further, the range of south-south cooperation continues to be underexplored due to the lack of its unanimously accepted definition. SSC is most often roughly characterised as a broad framework for collaboration among countries and often embraces interdisciplinary undertakings. These broad explanations have been disapproved for having lack in focus, clarity and definiteness. Recent developments in south-south cooperation have amplified the necessity for reaching a common understanding of the concept. Thus, devising a 
productive as well as well-functioning and widely accepted definition of south-south cooperation is extremely necessary as also it may contribute to campaigning for more competent policy framework for international development cooperation.

The critics discuss about difficulties going beyond the conceptual and definitional issues. In fact, the distinguishing features of the south-south cooperation have also been vastly debated. While the recognised modes of south-south cooperation represent advancement of wide-ranging instruments such as trade preference, investment promotion, educational scholarship etc., the comparative advantages of these instruments of cooperation, vis-à-vis the traditional ones is not frequently obvious. Lack of the procedures to maintain transparency and answerability time and again generate misperception around this mode of understanding.

Furthermore, present-day discussions on south-south cooperation are commonly disposed towards policy matters instead of genuine and practicable tactics to execution. The actual dissemination of knowledge and skills at a large scale, which is key to advancement in the mutual learning process, is yet to occur.

South-south cooperation has also been generally criticised as a principally inspired policy endorsement. A big point for conflict also criticized for not taking the conflicting interests among the developing countries into account. This demands a more pragmatic procedural tactic which will address the distinctive magnitudes of local agendas and fit them into broader south-south priority objectives, keeping the conflicting interests in mind. Furthermore, there is hardly any consensus on the topic of implementation instruments. Therefore, re-examining south-south cooperation paradigm has become the need of the hour.

Thus, while south-south cooperation is being thought as one of the important elements of the emergent international development assistance system, it is a prerequisite to take a closer and an arduous look at this changing phenomenon from the standpoints of multi-stakeholders. Multilateral core assistance continues to increase, though at a lower rate.

In conclusion, the study finds that multi-bi ODA guided and controlled through multilateral organisations contributes to disintegration, whether or not philanthropic assistance is included. In various cases, it can make the distribution of resources more complicated on the ground.

The propagation of bilateral assessments reveals the increased evaluation of public financial assets and amplified need for directing an already lacking assistance towards highly operative multilateral networks. Keeping up with the effectiveness commitments, mutual and international accountability requires assessments to put a stronger emphasis on the evidence from partner countries or "endusers" of the multilateral system. Therefore, with the emergence of upcoming challenges worldwide, contributors will make sure that channels for the delivery of financial assistance are used and, if needed, fortified before making new channels that pose threat to further fragmentation and complicate co-ordination at country level.

Participants under various multilateral organisations, funds, and programmes have a collective obligation to address the most significant challenges of the multilateral aid system that they fund and govern and to ensure effective funding, delivery and results at country level.

The following have been analysed to be the general ideologies to decrease the proliferation of multilateral channels:

- Utilising current channels, modifying where necessary, and addressing any legal and administrative obstacles that may prevent their use.

- Use the desire of global community for innovation initiatives and reform the existing multilateral system, permitting contributor distinguishability.

- Review multilateral organisations, funds and programmes regularly with the goal of decreasing them in number through merging them with one another without reducing the total volume of resources.

- Extend core or unallocated contributions to multilateral organisations, if relevant and possible.

- Make certain that new multilateral programmes and channels see a participation from multi-contributor arrangements; are time-bound, and should contain provisions for a mid-term review; and do not impose excessive reporting requirements if the creation of multilateral programmes and channels is unavoidable.

- Maintain country-level harmonisation among all contributors of development cooperation.

- Observe trends and development to restrict the proliferation of channels worldwide.

\section{References}

[1] Carroll, P. and Hynes, W. (2013), "Engaging with Arab aid donors: the DAC experience", IIIS Discussion Paper 424, April 2013, www.tcd.ie/iiis/documents/ discussion/pdfs/iiisdp424.pdf.

[2] Government of Chile, Ministry of Finance, website on budget and budget execution of the Chilean Agency for International Cooperation, www.dipres.gob.cl/595/ w3multipropertyvalues-14357-22027.html (accessed 10 October 2014)

[3] Government of China (2013), Website with central level expenditure budget tables, Ministry of Finance of the People's Republic of China, Beijing, http://yss.mof. gov.cn/zhengwuxinxi/caizhengshuju/ (accessed on 10 October 2014)

[4] Government of China (2014), "China's Foreign Aid (2014)", Information Office of the State Council of the People's Republic of China, Beijing.

[5] Government of Colombia (2013), Presidential Agency of International Cooperation of Colombia (APC), "Plan Estratégico Institucional” [Strategic Institutional Plan].

[6] Government of India, Ministry of External Affairs, website with annual budget documents, www.mea.gov.in/budget.htm?59/Budget (accessed on 10 October 2014) 
[7] Government of Indonesia (2011), "Prospective of Indonesia South-South cooperation 2011-14", National Coordination Team on South-South and Triangular Cooperation, South Jakarta.

[8] Government of Mexico, Mexican Agency for International Development Cooperation (AMEXID), website on 2010 and 2011 international co-operation figures, http://amexcid.gob.mx/images/ccid/ (accessed on 10 October 2014)

[9] Government of Qatar (2013), Department of International Development, "Foreign Aid Report 2010-2011".

[10] Government of Qatar (2014), Department of International Development, "Foreign Aid Report 2012".

[11] Government of South Africa, Treasury, website with annual national budget documents, www.treasury.gov.za/documents/national\%20budget/default.as px (accessed on 10 October 2014) OECD DAC Global Relations: www.oecd.org/dac/dac-global-relations.

[12] http://www.oecd.org/dac/aidarchitecture/2013\%20Multilateral\%20Aid\%20Report.pdf

[13] IPEA and ABC (2010), Brazilian Cooperation for International Development 2005-2009, Institute of Applied Economic Research (IPEA) and Brazilian Agency for Cooperation (ABC), Brasilia.

[14] IPEA and ABC (2013), Brazilian Cooperation for International Development 2010, Institute of Applied Economic Research (IPEA) and Brazilian Agency for Cooperation (ABC), Brasilia.

[15] Lomoy, Jon (2014), "2013 - An exceptional year for the DAC", www.oecd.org/dac/dac-global-relations/2013-anexceptional-year-for-the-dac.htm
[16] OECD. Estimates of the development co-operation programmes of: Brazil, Chile, China, Colombia, India, Indonesia, Mexico, Qatar and South Africa. February 2015

[17] OECD. Multilateral Aid Report. 2013.

[18] OECD. Development Co-operation by Countries Beyond the DAC. May 2015.

[19] .OECD (2014a), Development Co-operation Report 2014, www.oecd.org/dac/development-co-operation-report20747721.htm.

[20] OECD (2014b), "Non-DAC Countries and the Debate on Measuring Post-2015 Development Finance", document prepared for discussion at the DAC meeting of 10 February 2014,

www.oecd.org/dac/externalfinancingfordevelopment/documen tupload/DCD-DAC\%282014\%296-ENG.pdf.

[21] OECD (2011a), "Welcoming New Partnerships in International Development Co-operation", www.oecd.org/dac/47652500.pdf.

[22] OECD (2011b), "DAC Global Relations Strategy", www.oecd.org/dac/stats/49304654.pdf.

[23] Smith, K., Fordelone, T.Y. and Zimmermann, F. (2010), "Beyond the DAC: the Welcome Role of Other Providers of Development Co-operation", DCD Issues Brief, May 2010, OECD Development Co-operation Directorate, www.oecd.org/dac/45361474.pdf.

[24] Tortora, P. (2011), "Common ground between south-south and north-south cooperation principles". OECD-DAC Issues Brief. 